\title{
Turizmin Yerel Halk Üzerine Sosyo-Kültürel Etkileri: Şirince Köyü Örneği ${ }^{1}$
}

Neslihan Bahar BAŞTAN

Pamukkale Üniversitesi

Sosyal Bilimler Enstitüsü

Turizm İşletmeciliği Anabilim Dalı

bastanbahar@hotmail.com

Dr. Öğr. Üyesi Serap ALKAYA

Pamukkale Üniversitesi

Turizm Fakültesi,

Turizm İşletmeciliği Bölümü

salkaya@pau.edu.tr

\section{Özet}

Turizm, ülkeler için gelir getiren önemli bir sektör olmasının yanı sıra, ortaya çıktığından beri gelişmeyi ve büyümeyi sürdürme özelliği de taşıyan bir sektör olarak tanımlanmaktadır. Hem turizmin gelişip popüler olması hem de insanların gün geçtikçe turizm hareketi gerçekleştirebilmek için zamanının artması, turizmi yoğunlaştırmaktadır. Turizmin yoğun olarak gerçekleştirilmesi her yıl milyonlarca insanın etkileşim halinde olmasına neden olmaktadır. Bu etkileşim turist ve turist alan bölgedeki insanlar arasında gerçekleşmektedir. Toplumların birbirleri ile iç içe olması beraberinde bazı etkileri de ortaya çıkarmaktadır. Turizmin toplumlar üzerindeki etkileri; çevresel, sosyal, ekonomik ve sosyo-kültürel etki olarak ayrılmaktadır. Yapılan çalı̧̧manın amacı ise turizmin sosyo-kültürel etkisi üzerinedir. Turizmin toplum üzerinde gelenek göreneklerinden yaşam tarzına kadar olumlu ve olumsuz birçok sosyo-kültürel etkisi bulunmaktadır. Özellikle turizm ile iç içe bulunan turistik destinasyonlarda her gün binlerce farklı turist

\footnotetext{
${ }^{1}$ Bu çalışma Pamukkale Üniversitesi Sosyal Bilimler Enstitüsünde yürütülen Neslihan Bahar Baştan (2020) “Turizmin Yerel Halk Üzerine Sosyo-Kültürel Etkileri: Şirince Köyü Örneği” isimli (Yayımlanmamış) Yüksek lisans Tezinden üretilmiştir.
} 
profilleri ile etkileşimde bulunulması, bölgedeki insanların belli bir düzeyde turistlerin kültürlerinden etkilenmesine neden olabilmektedir. Etkilerin yoğunluğu ve azlığ bölgenin gelişmişlik düzeyi ile ilgilidir. Toplum ve turist arasındaki farklılı̆̆ın fazla olduğu noktalarda sosyo-kültürel etkiler yoğun yaşanırken, aradaki farkın az olduğu bölgelerde ise etkiler daha az görülmektedir. İzmir'in Selçuk ilçesine bağlı olan Şirince köyünde yapılan bu araştırma sonucunda, yerel halkın turizmin sosyo-kültürel etkilerinden ne ölçüde ve hangi noktalarda daha çok veya daha az etkilendiği ortaya konulmaktadır.

Anahtar Kelimeler: Turizm, Yerel Halk, Sosyo-Kültürel Etki, Şirince Köyü

Jel Kod: Z32

\title{
Socio-Cultural Effects of Tourism on Local People: The Example of Şirince Village
}

\begin{abstract}
Tourism is defined as a sector that has the feature of continuing development and growth since its emergence In addition to being an important income generating sector for countries. The development of tourism and the increase of people's leisure time intensifies tourism. The intensive realization of tourism causes millions of people to interact every year. This interaction takes place between the tourist and the people in the tourist area. The intertwining of societies also reveals some effects. Effects of tourism on societies; It is divided into environmental, social, economic and socio-cultural impact. The aim of the study is on the socio-cultural effect of tourism. Tourism has many positive and negative socio-cultural effects on society, from traditions to lifestyle. Interacting with thousands of different tourist profiles every day, especially in touristic destinations that are intertwined with tourism, can cause the people in the region to be influenced by the culture of the tourists at a certain level. The intensity and lowness of the effects are related to the development level of the region. While socio-cultural effects are intense at the points where the difference between the society and the tourist is high, the effects are less common in the regions where the difference is less. As a result of this research conducted in Şirince village, which is connected to Selçuk district of İzmir, it is revealed to what extent and at which points local people are affected more or less by the socio-cultural effects of tourism.
\end{abstract}

Key Words: Tourism, Local People, Socio-Cultural Impacts, Şirince Village.

Gel Code: Z32 


\section{Giriş}

Kitlesel olarak gerçekleştirilen turizm hareketi toplumların birbirleri ile yoğun etkileşimde bulunmasına neden olduğu gibi olumlu ve olumsuz etkilerini de beraberinde getirmektedir. Özellikle turist ve turist kabul eden bölgedeki yerel halk arasında birçok yönden iletişim gerçekleşmektedir. Turist, gittiği bölgedeki yerel halk ile iletişime geçtiği andan, tatilini bitirip yaşadığı yere dönene kadar iletişimi sürdürmektedir. Bu iletişimin sonucunda da etkiler meydana gelmektedir. Kısa vadede sosyo-kültürel etkiler kendini gösteremese de zaman geçtikçe toplum üzerinde yaşam tarzlarına, gelenek göreneklerinden giyim kuşamlarına kadar birçok toplumsal değere etkisi olduğu görülebilmektedir. Şirince köyü de turistik bir destinasyon olması nedeniyle gün içerisinde binlerce turisti ağırlamaktadır. Gelen her turist farklı bir kültürü yansıtmaktadır. Bu kadar farklı kültürün bir arada bulunması ve etkileşim gerçekleştirmesi turizmin Şirince köyünde de sosyo-kültürel etkilerini ortaya koymaktadır.

Araştırmada Şirince köyünün tarihsel gelişimi, turizmin gelişmesi ve ilerlemesi, turizm endüstrisi, turizm alanında yapılan çalışmalar ve turizm alanlarının yanı sıra turizmin sosyo-kültürel etkileri ele alınmıştır. Son olarak araştırmanın amacı doğrultusunda yapılan anketler sonucundan elde edilen bulgulara dayanarak araştırmada varılmak istenen sonuç ile ilgili açıklamalar yapılmıştır. Araştırma kapsamında yapılan literatür taramasında, Şirince köyünde turizmin yerel halk üzerine sosyo-kültürel etkilerinin değerlendirilmesine yönelik herhangi bir çalışmaya rastlanılmamıştır. Bu noktada çalışmanın yapılacak olan çalışmalara örnek olabilmesi hedeflenmiştir.

\section{2. Şirince Köyü Tarihi}

Şirince köyü, İzmir'in Selçuk ilçesinin 8 km doğusunda bulunan, 1922 yılına kadar Ortodoks Rumlarının kaldığı bir mübadele köyüdür. Köyün eski adının "Çirkince” olduğu bilinmektedir. 1910 yılına kadar sakin bir yaşam süren köylüler, Yunanistan'dan gelen göçmenler ile hareketlenmeye başlamıştır. Daha sonra Kurtuluş Savaşı sonrasında 1924'te göçmen mübadelesi ile Yunanistan'dan gelenler buraya tamamen yerleştirilir ve köy günümüzdeki haline gelmiştir. Köye girildiğinde ilk olarak mimari dokusu dikkatleri üzerine çekmektedir. Yaklaşı 200 ev Rum zamanından kalmıştır. Eğimli bir araziye sahip olmasından dolayı evler eğime paralel olarak 
dizilmiştir. Böylece sıralı bir görüntü oluşturmaktadır (Selçuk Kaymakamlığı, 2019). Çirkince köyü, Cumhuriyet döneminde İzmir Valisi Kazım Dirik'in emriyle "Şirince" şeklinde değiştirilip, resmi hale getirilmiştir (Türkiye Kültür Portalı, Şubat 2020). Şirince köyünde bir arada yaşayan farklı etnik grupları, bizlere çok kültürlülüğe bağlı mimari özellikler ve yapılar göstermektedir. Şirince köyünde büyük bir yoğunluğu oluşturan tarihi konutların dışında dini, ticari ve eğitim yapisı bulunmaktadır (Erturgut, 2014: 61).

\section{3. Şirince Köyü Turizmi}

Turizm, Şirince köyünde 1970'li yıllardan sonra gelişme göstermiştir. Yerel halkın anlatımına göre; Meryem Ana'yı ziyarete gelen acenteler Şirince köyünü de geziye dâhil etmişlerdir. Rivayete göre Meryem Ana doğuda, Şirince köyünün bulunduğu noktada gömülüdür. $O$ dönemden sonra tarihi köy olarak nitelendirilmeye başlanmıştır. O yıllarda yaz mevsiminde herkes tütüne gittiği için köyde kimsenin bulunmaması turizmin gelişmesi ile değişmiş ve herkes köyde kalmaya başlamıştır. Ev hanımları turistik eşyalar satmak için sergiler açmaya başlamıştır. Turizmden önce köyün geçim kaynağı zeytin, tütün ve yemişe (incir) dayanmaktadır. Fakat tütüncülük zamanla bitince meyve yetiştirilmeye başlanmıştır. Köyün şu an geçim kaynağı ise turizmdir (Evrensel, 2005). Turizm bölgede yaşayan insanların gelir seviyesini ve refah düzeyini artıran bir olgu olması sebebiyle ekonomik açıdan bölgenin kalkınmasına katkı sağlar (Unur, 2004: 115). Şirince köyünün girişinden başlayıp tüm köye yayılmış halde bulunan birbirinden farklı ürünlerin sergilendiği sergiler bölgede yaşayan halkın ana geçim kaynaklarındandır. Şirince'yi turistler tarafından cazip kılan önemli faktörlerden biri de sergilerin çeşitliliği ve köye verdiği doğal havadır. Son yıllarda insanların organik ürünlere olan ilgisi gün geçtikçe artmaktadır. Şirince de bu açıdan avantajlı bir destinasyondur. Sergiler; köyde yetiştirilen bitki, meyve ve sebzelerden elde edilen ve yerli kadınların el emekleri ile ortaya çıkardığı ürünlerden oluşmaktadır. Bu ürünlerin hem köyde yetiştirilip turistlere sunulması hem de tamamen doğal olmaları oldukça rağbet görmektedir. Yerel halkın geçim kaynakları arasında sergilerden elde edilen gelir de oldukça ön plandadır (Baştan, 2020).

Şirince köyü konumundan dolayı deniz, kum, güneş klasiğinin dışında, özgün kırsal mimarisi ile farklı alternatif turizm sunmaktadır. Şirince köyünün özgün mimari dokusunun köydeki kırsal ve kültürel turizmin artmasında rolü oldukça fazladır. Ayrıca, Selçuk, Efes, Meryem Ana ve Kuşadası 
gibi arkeolojik, tarihi, dini turistik merkezlere yakın olması, Şirince köyünün turistik değerini daha da arttırmaktadır (Kaya, 2012: 121). Şirince köyünde bulunan Rum evleri, günümüzde ilgi duyulan yapılar arasında yer almaktadır. Kentleşmenin yoğun yaşanması insanların kırsal özlemi ile birleşince bu tarz bölgelere ziyaretler artmaktadır. Mimarisi ile de dikkat çeken Şirince, insanların uğrak noktası olmaktadır. Bu tarz otantik mekanlar son yıllarda oldukça popüler bir hâl almıştır. Şirince bu alanda turistler tarafindan tercih edilen bir destinasyondur. Girişimci yerel halk artık kendi evlerini de birer işletmeye çevirmektedirler. İşletmeler; pansiyon, restoran ve kafe olmaktadır. Bu mimari dokuya sahip evlerin konaklama işletmesi olarak hizmet vermesi de bölgeye gelen turistler için daha çok ilgi çekici olmaktadır. Bu işletmelerde şömine başında köyün manzarası eşliğinde tatillerini geçirebilmektedirler (Baştan, 2020).

Maya takviminde yer alan kıyamet inanışı nedeniyle Şirince, 2012 yılında ismini tüm dünyaya duyurmuştur. Maya takvimine göre kopacak kıyametten etkilenmeyecek yerlerden biri Şirince köyü, diğeri ise Fransa'nın Bugarach köyüdür. Kıyamet günü olayı ile Şirince yurt dışında tanıtılması ününü artırmıştır (Anadolu Ajansı, 2018). Şirince köyü yılda 1,5 milyon turist ağırlamaktadır. Turistlerin yaklaşı üçte biri yabancı turistlerden oluşmaktadır (TRT Haber, 2018). Kırsal turizm, turistin çiftlik veya kır evinde çeşitli eğlenceli aktiviteler eşliğinde yaşadığı tatil deneyimidir (Fleischer ve Pizam, 1997). Kırsal alanların azalması ve kentleşmenin artması sonucunda doğaya olan değer de artmaya başlamıştır (OECD, 1994). Çevrenin kalitesi ve belirli özellikleri turistler için bir çekim noktası olmaktadır (Skanavis ve Sakellari, 2011). Kırsal turizm uzun zamandır ekonomik, sosyal kalkınmanın ve yenilenmenin sağlanması için bir araç olarak görülmektedir (Sharpley, 2002). Şirince'nin kırsal alanlarının elverişli ve turizme açık olması kırsal turizm anlayışının ortaya çıkmasına olanak sağlamaktadır. Şirince oldukça turist çeken bir köy olmasının yanı sıra, şehir hayatından bunalan, kendini kırsal alanlara vermek isteyen turist tipleri için de önemli bir yer olmaktadır. Buradaki toprakların değerlendirilmesi ve kırsal turizme katılması köydeki turizm anlayışında da gelişme sağlamaktadır. Aynı zamanda turizm de tüm yıla yayılabilmektedir (Baştan, 2020). Kırsal turizmin, iklimle bağlantılı olmadığı için mevsimlik olma özelliğinin olmaması sonucunda, kışın kayak yapılabilirken, baharda köylerde yürüyüşler yapılabilmekte, yaz ve sonbahar mevsimlerinde de özellikle tarımdan elde edilen ürünler cazip olduğu için çiftlikler daha çok ilgi görmektedir (Kınacı, Pehlivan Albuz ve Seyhan, 2011: 67). Kırsal turizm aynı zamanda kuş gözlemciliği, macera turizmi, çiftlik turizmi ve yayla turizmi gibi turizm türlerini de içermektedir (Kurt ve Bal, 2018). 
Üzüm bağları Şirince'nin büyük bir bölümünü kaplamaktadır ve yerel halk için önemli bir tarım ürünüdür. Toplanan üzümlerden, köyde bulunan şarap fabrikasında şarap üretilmektedir. Kendi markasına sahip olan Şirince, şarap satışlarında oldukça iyidir. Gün geçtikçe şarap çeşitlerinin artması, şarap satan dükkânların da çoğalmasını sağlamaktadır. Turistler köyün girişinden itibaren şarap dükkânları ile karşılaşmaktadırlar. Dükkânların otantik dokusu eşliğinde şarap tadımı yapabilir ve buralarda zaman geçirebilirler. Günümüzde sosyal medya kullanımının artması ile fotoğrafçılığında ön plana çıkması, insanların bu tarz otantik mekânlara karşı sempatisini arttırmıştır. Bu gibi yerlerin sosyal medyada paylaşımı turistlere istediklerini deneyimleri yaşamasını sağlamaktadır. Şarap dükkânlarının yanı sıra, köyde mahzenler de ilgi çekmektedir. Birçok şarap çeşidinin raflarda sergilenmesi, oldukça güzel bir görüntüye sahiptir (Baştan, 2020). Şirince'deki Artemis Şaraphanesi 1995 yılında kurulmuştur. Bu şaraphane 2004 yılında 3 milyon litre üretim kapasitesine sahipken 2,5 milyon litre şarap satmıştır. Şirince'yi çok sayıda yabancı turist ziyaret etmesine rağmen şarap tüketimi zamanları sınırlıdır ve turistlerin belli bir kısmı şarap alımı yapmaktadır. Yeterli pazarlama stratejisi ile Şirince'de yılda 4 milyon litre şarap satımı yapılabilir (Var, Kaplan ve Yurt, 2006: 12). Şarapların kalite standartları arttırılarak iyi bir pazarlama stratejisi ile daha iyi bir imaj sergilemesi mümkündür (Baştan, 2020). Şirince köyü sit alanı ilan edildiği için kültürel bir koruma alanıdır. Sit alanı ilan edilmesinden dolayı betonlaşma ve binaların yapılması engellenmiş durumdadır (Türkay ve Yalçın Kayıkçı, 2018: 652). Şirince’de başta özgün mimari dokusu olmak üzere kültürel unsurları belirgin olarak ön plana çıkmaktadır. Şirince köyünde kültürel etkinlikler 1980'li yıllardan itibaren artmaya başlamıştır (Semenderoğlu ve Çakıcıoğlu, 2007: 177).

\section{Turizmin Sosyo-Kültürel Etkileri}

Kültür, turistlerin belirli bir destinasyon seçimindeki en önemli motivasyonlarından birisidir (Correia, Kozak ve Ferradeira, 2013). Turizm faaliyetleri, insanların farklı kültürleri tanımasına olanak sağlayan sosyal bir olay olarak nitelendirilmektedir. Turistler, her gittiği yeri etkilediği gibi gittikleri yerlerdeki yerel halkı da etkilemektedirler. Bu etkileşim sayesinde toplumlar ve kültürler arasında bağ kurulmaktadır (Coğrafya Bilimi, 2017). Turizm, ekonomik etkilerinin dışında bir bütün olarak toplumları da etkilemektedir. Hayat tarzı ve gelenekler açısından da önemli bir role 
sahiptir. Turizm kitlesel bir hareket olduğu için turistler sürekli gittikleri bölgelere kendi dünya görüşlerini, anlayışlarını ve başka ülke insanları hakkındaki görüşlerini de taşımaktadırlar (Tayfun, 2002: 2). Yerel halk ile turist arasındaki etkileşim ve iletişim çeşitli şekillerde olmaktadır. Turistler gittikleri yerleri ziyaretleri sırasında sahilde, sokakta, mağazada, ören yerinde kısacası insanlarla etkileşimde oldukları her yerde kendi kültürlerine uygun olarak davranmaktadır. Turizmin sosyokültürel etkisi turistlerin gittikleri yerde gösterdikleri davranışları ile ilgilidir. Konu ile ilgili yapılan çalışmalar, turistlerin yerel halkın davranışlarını etkilediğini ve geleneksel yaşamlarında büyük değişeme sebep olduklarını ortaya koymuştur (Kınacı vd., 2011: 10). Turizmin geliştĭgi bölgelerde yaşayan yerel halk için turizm faaliyeti aynı zamanda çeşitli girişimcilik hareketleri ve istihdam yoluyla hayat standartlarını düzenleme aracı olmakta, kadınların da ekonomik açıdan işgücüne katılmasını yaygınlaştırmaktadır. Ayrıca bölgede turizm geliştikçe insanlarda bu gelişimden katkı sağlamaktadır (Avcıkurt, 2017: 58). İnsan kafasındaki anlam ve değerler, öncelikle bir kategorileşme, tasarlama ve kavramlaşma sürecini yaşamaktadır. Sonra kavramlaşan bu anlam ve değerler, objektifleşme süreci ile cisimleşirler ve nesnel bir gerçeklik haline gelirler. $\mathrm{Bu}$ etkileşim süreci içerisinde yer alan insan topluluğunun, meydana gelen olgularla bütünleşmesi, yani sosyalleşmesi, sosyo-kültürel olgunun doğuşunu ortaya koymaktadır (Yazıc1, 2002: 226).

Turizm etkilerinin turizm alanlarında ve destinasyonlarda sosyal yapının korunmasına katkıda bulunan olumlu bileşenler olduğu kabul edilirse, olumsuz sosyal ve kültürel etkilerin yerel toplulukların sosyal bütünlüğünü bozan ve bunlara zarar veren bileşenler olduğu sonucuna ulaşılabilir. Bununla birlikte, olumsuz sosyo-kültürel etkilerin her zaman yoğun turizm büyümesinin bir sonucu olarak ortaya çıkması veya ortaya çıkmasının diğer faktörler tarafindan başlatılması tartışılmalıdır (Jovičić, 2011: 604). Yerel halk ile bölgeyi ziyaret eden turistler arasındaki eğitim, refah ve kültür seviyesi birbirine ne kadar yakın olursa sosyal anlamda yaşanan değişim de azalmaktadır (Korkmaz, 1990: 411).

Turizm var olduğu yerdeki hayatı bütünüyle etkileyebilir. Bölgede yeni uygulamaların başlamasını sağlayabilir, farklı kültür ve milliyetten insanların etkileşim kurmasına ortam yaratarak barışçıl bir ortam oluşmasını sağlayabilir. Turizm sayesinde birçok insan farklı kültürler ile etkileşim halindedir. Farklı kültürlerin içinde bulunmak, insanların hayattaki deneyimlerini arttırırken aynı zamanda dünyaya farklı bir şekilde bakmasını sağlayabilir. Hiç tanımadıkları milletler ve kültürler hakkında bilgiler edinmek, ön yargıları yıkarken diğer yandan korkulan durumları da ortadan 
kaldırarak ilgi çekici hale getirmektedir. Turizmin olumsuz etkileri de mevcuttur. Yasal olmayan faaliyetler turizm aracılığıyla rahat yapılabilir hale gelmektedir. Çocuk yaştaki gençlerin alkol kullanması ve fazla tüketmesi sorun haline gelmektedir. Turizme ayak uydurmaya çalışırken kendi kültürlerinin değişmesine sebep olabilmektedirler. Bununla birlikte turizmde asıl olan tarihi ve doğal alanlar zarara uğrayabilmektedir. Turist bir bölgeye gitmeden önce o bölge hakkında bilgi sahibi olursa eğer gittiği bölgedeki ortama tam anlamıyla katılabilsin. Özellikle toplumsal farkl1lıklar göz önünde bulundurulduğunda ön bilgi edinilmesi gereklidir. Turistlerin kendi ülkelerinde gidecekleri yer ile ilgili gerekli şekilde haberdar edilmeleri gereklidir (Çalışkan, 2003: 132). Gürbüz'ün (2002) çalışmasına göre; özellikle küçük yerleşim yerleri turizmden olumsuz etkilenmektedir. Şirince'nin de küçük bir yerleşim yeri olması ve turizmin sebep olduğu olumsuz etkilerin ortaya konacak olması bakımından çalışma önemlidir.

Turistler gittikleri yerde insanları kendi davranışlarıyla etkilerken, kendileri de bu durumdan etkilenirler (Demircan, 2010: 123). Turizm sebebi ile bu etki altında kalan turistleri ve yerel halk1 yaşam tarzları, geleneksel yapıları, değerleri, insan ilişkileri gibi konular çerçevesinde incelemek olanaklıdır (Civelek, 2010: 333). Turizm sosyolojisi turistlerin farklı bir yeri ziyaretleri sırasında yerel halk ile kurdukları etkileşimi ve turizmin bu etkileşimdeki etkilerini inceleyen bir alandır (Usta, 2008: 6).

\section{Yöntem}

Araştırmanın evrenini, Şirince köyünde yaşayan 468 (www.nufusu.com, 16.05.2019) kişi oluşturmaktadır. Örneklem büyüklüğü belirlenirken Yazıcıŏglu ve Erdoğan'ın (2004) örneklem tablosu kullanılmıştır. Tabloya göre, 0,05 anlamlılık seviyesi ve $\pm 0,05$ hata oranında, evren büyüklüğü 500 olduğunda örneklem büyüklügünün 217 olması gerekmektedir. Araştırmada 2020 yılının Ocak ayında kolayda örnekleme yöntemi ile toplam 309 kişiye ulaşılarak anket yapılmıştır. Turizmin yerel halk üzerindeki sosyo-kültürel etkilerini ortaya koymayı hedefleyen bu çalışmada, veri toplama tekniği olarak anket tercih edilmiştir. Anket toplamda üç kısımdan meydana gelmiştir. Birinci kısımda yerel halkın demografik profilini ortaya çıkarmak için altı adet soru sorulmuştur. Anketin ikinci kısmında katılımcıların, Şirinceli olup olmadıkları, bölgeyi ziyare eden turistlerle iletişimde olup olmadıklanı, kullandıkları yabancı diller, iletişim kurma amaçları 
ve turizm ile ilgili bir iş yapıp yapmadıkları saptamak amacıyla beş adet kapalı uçlu soru sorulmuştur. Anketin üçüncü kısmında ise, turizmin yerel halk üzerindeki sosyo-kültürel etkilerini ortaya koymak amacıyla Demircan'ın (2010) çalışmasında güvenilirliği tespit edilmiş beşli likert tipinde (1: Kesinlikle Katılmıyorum, 5: Kesinlikle Katılıyorum) otuz adet kapalı uçlu bir ölçekten yararlanılmıştır. Hazırlanan anketler kolayda örnekleme yöntemi ile uygulanmıştır. Ölçeğin güvenilirliğini test etmek amacıyla tüm boyutlara ilişkin ayrı ayrı güvenilirlik (Cronbach's Alpha) değerleri hesaplanmıştır. Elde edilen tüm veriler istatistik paket programında katılımcıların sosyokültürel boyutları ortaya çıkarmak ve anketin geçerliliğini sağlamak amacıyla faktör analizi, gruplar arasındaki farklılıkları tespit etmek amacıyla Kruskal-Wallis testi ve Mann-Whitney U testleri kullanılarak analiz edilmiştir.

\section{Araştırma Bulguları ve Yorumları}

\subsection{Demografik Özelliklere İlişsin Bulgular}

Araştırmadaki ana değişkenlerden bir tanesi olan ve ölçülmesi hedeflenen değişken Şirince köyünde yaşayan yerel halkın nasıl bir profile sahip olduğudur. Bu bölümde, araştırmaya katılan yerel halka ait demografik özelliklere ilişkin bulguların frekans (f) ve yüzde (\%) dağılımlarının tablosu aşağıda verilmiştir.

Tablo 1. Araştırmaya Katılanların Demografik Özellikleri

\begin{tabular}{|l|l|c|c|}
\hline Değisskenler & Seçenekler & Frekans & Yüzde \\
\hline Cinsiyet & Kadın & 143 & 46,3 \\
& Erkek & 166 & 53,7 \\
& Genel Toplam & 309 & 100,0 \\
\hline Yaş & $20-30$ & 90 & 29,1 \\
& $31-40$ & 82 & 26,5 \\
& $41-50$ & 58 & 18,8 \\
& $51-60$ & 54 & 17,5 \\
& 61 ve üzeri & 25 & 8,1 \\
& Genel Toplam & 309 & 100,0 \\
\hline Eğitim durumu & İlkokul & 92 & 29,8 \\
& Lise & 125 & 40,5 \\
& Ön Lisans & 41 & 13,3 \\
& Lisans ve üzeri & 51 & 16,5 \\
\hline
\end{tabular}




\begin{tabular}{|l|l|c|c|}
\hline & Genel Toplam & 309 & 100,0 \\
& & & \\
\hline Meslek & Çiftçi & 22 & 7,1 \\
& Tüccar & 2 & 0,6 \\
& Esnaf & 148 & 47,9 \\
& Serbest Meslek & 28 & 9,1 \\
& İşçi & 37 & 12,0 \\
& Devlet Memuru & 4 & 1,3 \\
& Emekli & 2 & 0,6 \\
& Ev Hanımı & 31 & 10,1 \\
& Diğer & 35 & 11,3 \\
& Genel Toplam & 309 & 100,0 \\
\hline Aylık geliri & 1000 TL'den az & 34 & 11,0 \\
& 1001-1500 TL & 25 & 8,1 \\
& 1501-2000 TL & 51 & 16,5 \\
& 2001-3000 TL & 116 & 37,5 \\
& 3001-4000 TL & 51 & 16,5 \\
& 4001 ve üzeri & 32 & 10,4 \\
& Genel Toplam & 309 & 100,0 \\
\hline Şirince'de & 1 yıldan az & 22 & 7,1 \\
yaşama süresi & $1-5$ y1l & 70 & 22,7 \\
& 6-10 y1l & 44 & 14,2 \\
& 11-15 y1l & 37 & 12,0 \\
& 16-20 y1l & 14 & 4,5 \\
& 21 yıl ve üzeri & 122 & 39,5 \\
& Genel Toplam & 309 & 100,0 \\
\hline
\end{tabular}

Araştırmaya katılan yerel halkın; cinsiyeti, yaşı, eğitim durumu, mesleği, aylık geliri ve Şirince'de yaşama süreleri ile ilgili demografik değişkenler ile ilgili bulgular frekans ve dağılımları ile yukarıdaki Tablo 1'de gösterilmektedir.

Araştırmaya katılanların; \%46,3'ü (f=143) kadın, \%53,7'si ( $\mathrm{f}=166)$ erkektir. Araştırmaya katılanların; \%29, 1 ' i ( $\mathrm{f}=90)$ 20-30 yaş, \%26,5' i ( $\mathrm{f}=82$ ) 31-40 yaş, \%18,8' $\mathrm{i}(\mathrm{f}=58)$ 41-50 yaş, \%17,5 (f=54) 51-60 yaş ve \%8, 1’i (f=25) 61 ve üzeri yaş aralığındadır. Araştırmaya katılanların; \%29,8’i ( $\mathrm{f}=92$ ) ilkokul, \%40,5'i ( $\mathrm{f}=125$ ) lise, \%13,3’ü ( $\mathrm{f}=41$ ) ön lisans, \%16,5’ $\mathrm{i}(\mathrm{f}=51)$ lisans mezunudur. Araştırmaya katılanların; \% 7,1 'i ( $\mathrm{f}=22$ ) çiftçi, \%0,6'sı (f=2) tüccar, \%47,9'u (f=148) esnaf, \%9, 1'i ( $\mathrm{f}=28)$ serbest meslek, \%12,0'si ( $\mathrm{f}=37)$ işçi, \%1,3’ü (f=4) devlet memuru, \%0,6'sı ( $\mathrm{f}=2$ ) emekli, $\% 10,1^{\prime}$ i ( $\mathrm{f}=31$ ) ev hanımı, \%11,3'ü (f=35) ise diğer meslek grubundadır. Araştırmaya katılanların; \%11,0'i (f=34) 1000 TL'den az, \%8,1'i (f=28) 1001-1500 TL, \%16,5'i (f=51) 1501-2000 TL, \%37,5'i (f=116) 2001-3000 TL, \%16,5'i (f=51) 3001-4000 TL, \%10,4'ü (f=32) 4001 ve üzeri 
karşılığında çalışmaktadır. Araştırmaya katılanların; \%7,1 'i (f=22) 1 yıldan az, \%22,7'si (f=70) 1 5 y11, \%14,2'si (f=44) 6-10 y11, \%12,0'si (f=37) 11-15 y11, \%4,5'i (f=14) 16-20 y1l, \%39,5'i (f=122)

21 yıl ve üzeri süredir Şirince'de yaşamaktadır.

\subsection{Katılımcıların Şirince'nin Yerlisi Olup Olmadığı, Turistlerle İletişim Durumu ve İletişim Yabancı Dili, İletişim Sebebi ve Turizm Sektörü Çalışanı Olup Olmadığına İlişkin Elde Edilen Bulgular}

Şirince köyünde araştırmaya katılan halkın köyün yerlisi olup olmadı̆̆ı, gelen turistlerle iletişim kurup kurmadığı, turistlerle hangi dilde iletişim kurdukları, turistlerle iletişim kurma sebepleri ve katılımcıların turizm sektöründe çalışıp çalışmadıklarına ilişkin elde edilen bulgular frekans (f) ve yüzde (\%) dağılımları ile aşağıdaki tablolarda verilmiştir.

Tablo 2. Katılımcıların Şirince’nin Yerlisi Olup Olmadığının Frekans ve Yüzdesi

\begin{tabular}{|l|l|c|c|}
\hline \multirow{3}{*}{$\begin{array}{l}\text { Şirince doğumlu } \\
\text { musunuz? }\end{array}$} & \multicolumn{1}{|c|}{ Cevap } & f & $\%$ \\
\cline { 2 - 4 } & Evet & 132 & 42,7 \\
\cline { 2 - 4 } & Hayır & 177 & 57,3 \\
\cline { 2 - 4 } & Toplam & 309 & 100,0 \\
\hline
\end{tabular}

Araştırmaya katılanların; \%42,7'si (f=132) Şirince doğumlu iken, \%57,3’ü (f=177) ise Şirince doğumlu değildir.

Tablo 3. Katılımcıların Turistlerle İletişim Durumu Frekans ve Yüzdesi

\begin{tabular}{|l|l|c|c|}
\hline Şirince'yi ziyaret & \multicolumn{1}{|c|}{ Cevap } & f & $\%$ \\
\cline { 2 - 4 } $\begin{array}{l}\text { eden turistlerle } \\
\text { iletişim kuruyor } \\
\text { musunuz? }\end{array}$ & Evet & 286 & 92,6 \\
\cline { 2 - 4 } & Hayır & 23 & 7,4 \\
\cline { 2 - 4 } & Toplam & 309 & 100,0 \\
\hline
\end{tabular}

Araştırmaya katılanların; \%92,6’sı ( $\mathrm{f}=286)$ turistlerle iletişim kurmaktadır. \%7,4’ü (f=23) ise turistlerle iletişim kurmamaktadır. 
Tablo 4. Katılımcıların Turistlerle İletişimde Kullandıkları Yabancı Dile İlişkin Frekans ve Yüzdesi

\begin{tabular}{|l|l|c|c|}
\hline \multirow{3}{*}{$\begin{array}{l}\text { Şirince'yi ziyaret } \\
\text { eden turistlerle } \\
\text { hangi dilde iletişim } \\
\text { kuruyorsunuz? }\end{array}$} & \multicolumn{1}{|c|}{ Yabanc1 Dili } & $\mathrm{f}$ & $\%$ \\
\cline { 2 - 4 } & Almanca & 15 & 4,9 \\
\cline { 2 - 4 } & Arapça & 2 & 0,6 \\
\cline { 2 - 4 } & Çince & 17 & 5,5 \\
\cline { 2 - 4 } & İngilizce & 2 & 57,3 \\
\cline { 2 - 4 } & İtalyanca & 6 & 0,6 \\
\cline { 2 - 4 } & Korece & 90 & 29,1 \\
\cline { 2 - 4 } & $\begin{array}{l}\text { Yabanc1 Dil } \\
\text { Bilmiyor }\end{array}$ & & 100,0 \\
\cline { 2 - 4 } & Genel Toplam & 309 & \\
\hline
\end{tabular}

Araştırmaya katılanların; \%4,9'u (f=15) Almanca, \%0,6'sı (f=2) Arapça, \%5,5'i (f=17) Çince, \%57,3’ü (f=177) İngilizce, \%0,6’sı (f=2) İtalyanca, \%1,9’u (f=6) Korece konuşabilmektedir. $\% 29,1$ 'i ( $\mathrm{f}=90)$ ise yabancı dil bilmemektedir.

\section{Tablo 5. Katılımcıların Turistlerle İletişim Sebebine İlişskin Frekans ve Yüzdesi}

\begin{tabular}{|l|l|c|c|}
\hline $\begin{array}{l}\text { Şirince'yi ziyaret } \\
\text { eden turistlerle ne }\end{array}$ & \multicolumn{1}{|c|}{ Amaç } & $\mathrm{f}$ & $\%$ \\
\cline { 2 - 4 } tür bir iletişim & Yabancı dil geliştirme & 16 & 5,2 \\
\cline { 2 - 4 } kuruyorsunuz? & Arkadaşl1k etme & 5 & 1,6 \\
\cline { 2 - 4 } & Ekonomik & 275 & 89,0 \\
\cline { 2 - 4 } & $\begin{array}{l}\text { Yabancı bir kültürü } \\
\text { tanıma }\end{array}$ & 5 & 1,6 \\
\cline { 2 - 4 } & Diğer & 8 & 2,6 \\
\cline { 2 - 4 } & Toplam & 309 & 100,0 \\
\hline
\end{tabular}

Araştırmaya katılanların; \%5,2'si (f=16) yabancı dil geliştirme, \%1,6'sı (f=5) arkadaşlık etmek, \%89,0’u ( $\mathrm{f}=275)$ ekonomik, \%1,6 $(\mathrm{f}=5)$ yabanc1 bir kültürü tanıma ve \%2,6’s1 $(\mathrm{f}=8)$ ise diğer sebeplerden dolayı turistlerle iletişim kurmaktadır.

Tablo 6. Katılımcıların Turizm Sektörü Çalışanı Olup Olmadığına İlişkin Frekans ve Yüzdesi

\begin{tabular}{|l|l|c|c|}
\hline Turizm sektöründe & \multicolumn{1}{|c|}{ Cevap } & f & $\%$ \\
\cline { 2 - 4 } faaliyet gösteren \\
bir işletmede mi & Evet & 242 & 78,3 \\
\cline { 2 - 4 } çalışıyorsunuz? & Hayır & 67 & 21,7 \\
\cline { 2 - 4 } & Toplam & 309 & 100,0 \\
\hline
\end{tabular}


Araştırmaya katılanların; \% 78,3’ü ( $\mathrm{f}=242)$ turizmde faaliyet gösteren bir işletmede çalışmaktadır. \%21,1'i ( $\mathrm{f}=67)$ ise farklı sektörlerde çalışmaktadırlar.

Tablo 7. Turizmin Sosyo-Kültürel Etki Algısı Ölçeği Faktör Analizi

\begin{tabular}{|c|c|c|c|c|c|}
\hline & Yük & $\underset{\text { Değer }}{\ddot{O} z}$ & $\begin{array}{l}\text { Açıklanan } \\
\text { Varyans \% }\end{array}$ & Ortalama & Güvenirlik \\
\hline 1. Faktör: Olumsuz Etki & & 3,075 & 23,65 & 2,3064 & 0,843 \\
\hline $\begin{array}{l}\text { Şirince'de turizm faaliyetleri } \\
\text { gençlerin tutum ve } \\
\text { davranışlarını olumsuz yönde } \\
\text { etkilemektedir. }\end{array}$ & 0,74 & & & & \\
\hline $\begin{array}{l}\text { Turizm Şirince'de alkol ve } \\
\text { uyuşturucu gibi zararlı } \\
\text { alışkanlıkların yaygınlaşmasına } \\
\text { sebep olmaktadır. }\end{array}$ & 0,76 & & & & \\
\hline $\begin{array}{l}\text { Turizm sezonunda Şirince'de } \\
\text { kavga ve darp olayları } \\
\text { artmaktadır. }\end{array}$ & 0,71 & & & & \\
\hline $\begin{array}{l}\text { Turizm Şirince'de fuhuşun } \\
\text { artmasına sebep olmaktadır. }\end{array}$ & 0,47 & & & & \\
\hline $\begin{array}{l}\text { Şirince gelenek, örf ve adetleri } \\
\text { turizmden olumsuz yönde } \\
\text { etkilenmektedir. }\end{array}$ & 0,77 & & & & \\
\hline $\begin{array}{l}\text { Turizm Şirince’nin yerel } \\
\text { kültürünü olumsuz yönde } \\
\text { etkilemektedir. }\end{array}$ & 0,73 & & & & \\
\hline $\begin{array}{l}\text { 2. Faktör: Olumlu Etki ve } \\
\text { Etkileşim }\end{array}$ & & 2,122 & 16,32 & 4,1294 & 0,551 \\
\hline $\begin{array}{l}\text { Şirince halkı turistlerle iyi } \\
\text { ilişkiler kurma isteğinde olup } \\
\text { daha fazla turistin gelmesini } \\
\text { istemektedir. }\end{array}$ & 0,61 & & & & \\
\hline $\begin{array}{l}\text { Turizm Şirince halkının daha } \\
\text { hoşgörülü olmasını sağlar. }\end{array}$ & 0,38 & & & & \\
\hline $\begin{array}{l}\text { Şirince halkı turistlere karşı } \\
\text { saygılı ve arkadaşça } \\
\text { davranmaktadır. }\end{array}$ & 0,80 & & & & \\
\hline $\begin{array}{l}\text { Turistler Şirince halkına karşı } \\
\text { saygılı ve arkadaşça } \\
\text { davranmaktadır. }\end{array}$ & 0,76 & & & & \\
\hline 3. Faktör: Kültürel Etki & & 1,704 & 13,10 & 3,7907 & 0,597 \\
\hline
\end{tabular}




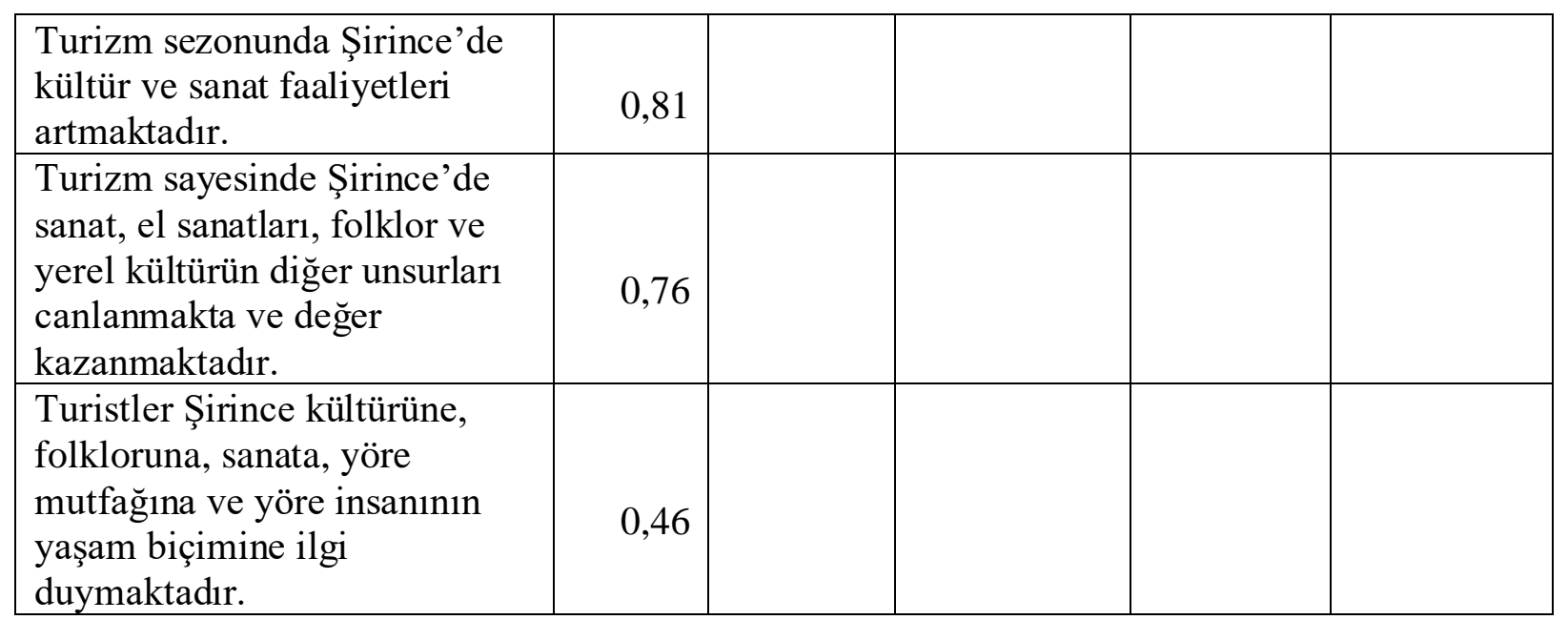

Faktör çıkarma metodu: Temel bileşenler analizi Döndürme metodu: Varimax

Kaiser-Meyer-Olkin Örneklem Yeterliliği: 0,696

Bartlett's Küresellik Testi için Ki-Kare: 1338,836; p<0,0001

Açıklanan toplam varyans: \%56,088; Ölçeğin tamamı için güvenirlik katsayısı: 0,685

Yanıtlar: 1: Kesinlikle Katılmıyorum, 2: Katılmıyorum, 3: Kararsızım, 4: Katılıyorum, 5:

Kesinlikle Kat1liyorum

Tablo 7'de turizmin yerel halk üzerindeki sosyo-kültürel etki algısı ölçeğinin faktör analizi sonuçları bulunmaktadır. Ölçeğin KMO testi \%69 olarak tespit edilmiştir. Değerin 0,50'den büyük olması, veri setinin faktör analizi için elverişli olduğunu göstermektedir. Analiz sonucunda 17 maddenin korelasyon katsayıları düşük oluğu için ölçekten çıkarılmıştır. Yapılan faktör analizi sonucunda 13 madde öz değeri 1 ya da 1'den büyük 3 faktör altında bir araya gelmiştir. Ölçeğin güvenirlik katsayısı 0,685 olurken, birinci boyutun güvenirlik katsayısı 0,843, ikinci boyutun güvenirlik katsayısı 0,551 ve üçüncü boyutun güvenirlik katsayısı 0,597'dir. Bu değerler hem ölçeğin hem de üç faktörün güvenilir olduğunu göstermektedir. Faktörlerin kapsadıkları ifadelerin ortaya çıkardığı ana düşünceler ele alınarak, adlandırma yapılmıştır. Birinci faktörde 6 madde toplanmıştır. $\mathrm{Bu}$ maddeler değerlendirildiğinde, turizmin yerel halk üzerindeki olumsuzlukları ortaya çıkmaktadır. Bu nedenle birinci faktöre "Olumsuz Etki" adı verilmiştir. İkinci faktör ise 4 maddeden oluşmaktadır. Bu maddeler turizmin olumlu etkileri ve turistlerle etkileşimlerini ortaya çıkardığı için "Olumlu Etki ve Etkileşim” adı verilmiştir. Üçüncü faktör ise 3 maddeden oluşmaktadır. Bu 3 madde kültür ve sanatın yerel halka kazandırdıkları ile ilgili olduğu için "Kültürel Etki" olarak adlandırılmıştır.

Veri setinin normallik testi Kolmogorov-Simirnov ve Shapiro Wilk testleri aracıllı̆ıyla yapılmaktadır. Kolmogorov-Simirnov testi sonucunu gösteren değerler Tablo 8'de yer almaktadır. 
Tablo incelendiğinde üç boyutunda anlamlılık değeri 0,000 olarak bulunmuştur. Bu değerin 0,05'ten küçük olması verilerin normal dağılıma uymadığını göstermektedir. Bu sebeple değişkenler arasındaki farklılıkları tespit etmede parametrik olmayan Kruskal-Wallis Testi ve Mann-Whitney U Testi yöntemleri kullanılmıştır.

Tablo 8. Normallik Testi

\begin{tabular}{|c|c|c|c|}
\hline Değişkenler & N & $\begin{array}{r}\text { Kolmogorov- } \\
\text { Smirnov Z Değeri }\end{array}$ & p \\
\hline Olumsuz Etki Etki ve & 309 & 0,150 & 0,000 \\
\hline $\begin{array}{c}\text { Olumlu } \\
\text { Etkileşim }\end{array}$ & 309 & 0,170 & 0,000 \\
\hline Kültürel Etki & 0,209 & 0,000 \\
\hline
\end{tabular}

Araştırmanın bu bölümünde yerel halkın demografik özellikleri (cinsiyet, yaş, eğitim düzeyi, Şirince'de yaşama süreleri, aylık gelir) ile turizmin sosyo-kültürel etkileri (olumlu etki, olumlu etki ve etkileşim, kültürel etki) arasındaki istatistiksel açıdan anlamlı farklılıklar olup olmadığı ile ilgili farklılık analizleri (Mann Whitney U Testi ve Kruskal-Wallis Testi) ile tespit edilmeye çalışılmıştır. Turizmin sosyo-kültürel etkilerinden olumsuz etkinin yaş, eğitim durumu, Şirince'de yaşama süresi ve aylık gelir değişkenlerine göre farklılaşıp farklılaşmadığını saptamak amacıyla yapılan Kruskal-Wallis testinin sonuçları Tablo 9'da yer almaktadır. Yapılan Kruskal-Wallis testi sonucunda yerel halkın yaş, eğitim durumu ve Şirince' de yaşama süresi ile turizmin olumsuz etkisi boyutu arasında anlamlı bir farklılık olmadığı tespit edilirken; aylık gelirleri $(p=0,006<0,01)$ ile turizmin olumsuz etkisi arasında anlamlı bir farklılık olduğu tespit edilmiştir.

Tablo 9. Olumsuz Etkinin Yaş, Eğitim Durumu, Şirince’de Yaşama Süresi ve Aylık Gelir Değişkenlerine Göre Farklılığını Gösteren Kruskal-Wallis Tablosu

\begin{tabular}{|c|c|c|c|c|c|}
\hline Değişken & $\mathbf{N}$ & $\begin{array}{c}\text { Sira } \\
\text { Ortalaması }\end{array}$ & Ki-Kare & $\begin{array}{r}\text { Serbestlik } \\
\text { Derecesi }\end{array}$ & $\mathbf{p}$ \\
\hline \multicolumn{6}{|c|}{ Yaş } \\
\hline $20-30$ & 90 & 155,53 & \multirow{6}{*}{3,406} & \multirow{6}{*}{4} & \multirow{6}{*}{0,492} \\
\hline $31-40$ & 82 & 152,23 & & & \\
\hline $41-50$ & 58 & 152,47 & & & \\
\hline $51-60$ & 54 & 147,14 & & & \\
\hline 61 ve üzeri & 25 & 185,06 & & & \\
\hline Toplam & 309 & & & & \\
\hline
\end{tabular}




\begin{tabular}{|c|c|c|c|c|c|}
\hline \multicolumn{4}{|c|}{ Aylık Gelir } & \multirow{8}{*}{5} & \multirow{8}{*}{$0,006^{*}$} \\
\hline 1000 'den az & 34 & 203,51 & \multirow{7}{*}{16,152} & & \\
\hline $1001-1500$ & 25 & 162,00 & & & \\
\hline $1501-2000$ & 51 & 132,74 & & & \\
\hline $2001-3000$ & 116 & 146,88 & & & \\
\hline $3001-4000$ & 51 & 167,92 & & & \\
\hline $\begin{array}{l}4001 \text { ve } \\
\text { üzeri }\end{array}$ & 32 & 142,33 & & & \\
\hline Toplam & 309 & & & & \\
\hline \multicolumn{6}{|c|}{ Ĕgitim } \\
\hline İlkokul & 92 & 160,64 & \multirow{5}{*}{1,526} & \multirow{5}{*}{3} & \multirow{5}{*}{0,676} \\
\hline Lise & 125 & 154,45 & & & \\
\hline Önlisans & 41 & 140,44 & & & \\
\hline $\begin{array}{l}\text { Lisans ve } \\
\text { üzeri }\end{array}$ & 51 & 157,87 & & & \\
\hline Toplam & 309 & & & & \\
\hline \multicolumn{6}{|c|}{ Şirince'de Yaşama Süresi } \\
\hline 1 yildan az & 22 & 133,82 & \multirow{7}{*}{7,560} & \multirow{7}{*}{5} & \multirow{7}{*}{0,182} \\
\hline $1-5$ y1l aras 1 & 70 & 153,90 & & & \\
\hline $6-10$ yil aras1 & 44 & 171,92 & & & \\
\hline $\begin{array}{c}11-15 \text { y1l } \\
\text { aras1 }\end{array}$ & 37 & 131,80 & & & \\
\hline $\begin{array}{c}16-20 \text { y1l } \\
\text { aras1 }\end{array}$ & 14 & 129,68 & & & \\
\hline $\begin{array}{c}21 \text { yil ve } \\
\text { üzeri }\end{array}$ & 122 & 163,29 & & & \\
\hline Toplam & 309 & & & & \\
\hline
\end{tabular}

*p $<0,01$ anlamlılık düzeyinde ilişki anlamlı

Tablo 9'a ait veriler değerlendirilecek olursa; katılımcıların aylık gelir değişkeni $(p=0,006<0,01)$ ile turizmin olumsuz etkisi arasında anlamlı bir farklılık olduğu tespit edilmiştir. Uygulanan Kruskal-Wallis Testi sonucunda incelenen aylık gelir değişkeni sıra ortalamalarına göre; turizmin olumsuz etkisini gören en yüksek grup 1000 TL'den az aylık gelir elde edenlerdir. Bu aylık gelir düzeyinde yer alan katılımcı yerel halk, diğer aylık gelire sahip olanlara göre turizmin olumsuz etkilerini daha çok yaşamaktadır. Turizmden düşük gelir elde eden yerel halk açısından, turizm fayda sağlamamaktadır. $\mathrm{Bu}$ düşüncede bulunulmasının sebebi hayat standartlarının düşük olmasıdır. Turizmin olumsuz etkilerinden en az etkilenen grup ise 1501-2000 TL arasında aylık gelir elde edenlerdir. Bu grupta yer alan yerel halkın çoğunluğunu işletmelerde çalışan genç yaş grubu oluşturmaktadır. Turizmden memnun olup yeterli geliri elde ettiklerini düşünüp, turizmin olumsuz etkilerinden diğer grupta yer alanlara göre daha az hissetmektedirler. 
Aylık gelir değişkenine göre diğer gelir gruplarındaki sıra ortalamaları incelendiğinde; turizmin olumsuz etkilerinden en yüksek etkilenen 1000 TL'den az gelir edenlerden sonra gelen grup 3001 4000 TL'dir. Daha sonrasinda sirası ile 1001-1500 TL aras1 ve 2001-3000 TL aras1 ve 4001 ve üzeri gelir elde edenler gelmektedir. Sonuçlar değerlendirildiğinde; turizmden elde edilen gelir düzeyi yerel halkın turizmin olumsuz etkilerini hissetme yoğunluğu ile ilişkilidir. Gelir düzeyi düştükçe hayat standardı düşen yerel halka göre turizmin olumsuz etkileri yoğun yaşanırken, gelir düzeyi ve hayat standardı normal veya yüksek olan yerel halk açısından turizmin olumsuz etkileri daha az yaşanmaktadır. Bunun nedeni ise turizmden elde edilen gelir ile turizmden memnuniyet duyma oranının aynı olmasıdır.

Olumlu etki ve etkileşimin yaş, eğitim durumu, Şirince'de yaşama süresi ve aylık gelir değişkenlerine göre farklılaşıp farklılaşmadığını saptamak amacıyla yapılan Kruskal-Wallis testinin sonuçları Tablo 10'da yer almaktadır. Yapılan Kruskal-Wallis Testi sonucunda yerel halkın yaş ve eğitim durumu ile olumlu etki ve etkileşim boyutu arasında anlamlı bir farklılık tespit edilemezken; aylık gelir $(p=0,012<0,05)$ ve Şirince köyünde yaşama süresi $(p=0,027<0,05)$ değişkeni ile olumlu etki ve etkileşim boyutu arasında anlamlı bir farklılık olduğu tespit edilmiştir.

Tablo 10. Olumlu Etki ve Etkileşimin Yaş, Eğitim Durumu, Şirince'de Yaşama Süresi ve Aylık Gelir Değişkenlerine Göre Farklılığını Gösteren Kruskal-Wallis Tablosu

\begin{tabular}{|c|c|c|c|c|c|}
\hline Değişken & $\mathbf{N}$ & $\begin{array}{c}\text { Sira } \\
\text { Ortalaması }\end{array}$ & Ki-Kare & $\begin{array}{c}\text { Serbestlik } \\
\text { Derecesi }\end{array}$ & $\mathbf{p}$ \\
\hline \multicolumn{6}{|c|}{ Yaş } \\
\hline $20-30$ & 90 & 152,56 & \multirow{6}{*}{1,196} & \multirow{6}{*}{4} & \multirow{6}{*}{0,879} \\
\hline $31-40$ & 82 & 158,94 & & & \\
\hline $41-50$ & 58 & 150,35 & & & \\
\hline $51-60$ & 54 & 162,93 & & & \\
\hline 61 ve üzeri & 25 & 144,52 & & & \\
\hline Toplam & 309 & & & & \\
\hline \multicolumn{6}{|c|}{ Aylık Gelir } \\
\hline 1000'den az & 34 & 166,43 & \multirow{6}{*}{14,677} & \multirow{6}{*}{5} & \multirow{6}{*}{$0,012^{*}$} \\
\hline $1001-1500$ & 25 & 205,54 & & & \\
\hline $1501-2000$ & 51 & 169,24 & & & \\
\hline $2001-3000$ & 116 & 146,41 & & & \\
\hline $3001-4000$ & 51 & 142,89 & & & \\
\hline $\begin{array}{c}4001 \text { ve } \\
\text { üzeri }\end{array}$ & 32 & 131,14 & & & \\
\hline
\end{tabular}




\begin{tabular}{|c|c|c|c|c|c|}
\hline Toplam & 309 & & & & \\
\hline \multicolumn{6}{|c|}{ Eğitim } \\
\hline İlkokul & 92 & 154,68 & \multirow{5}{*}{6,336} & \multirow{5}{*}{3} & \multirow{5}{*}{0,096} \\
\hline Lise & 125 & 165,82 & & & \\
\hline Önlisans & 41 & 126,34 & & & \\
\hline $\begin{array}{c}\text { Lisans ve } \\
\text { üzeri }\end{array}$ & 51 & 152,10 & & & \\
\hline Toplam & 309 & & & & \\
\hline \multicolumn{6}{|c|}{ Şirince'de Yaşama Süresi } \\
\hline 1 y1ldan az & 22 & 107,93 & \multirow{7}{*}{12,617} & \multirow{7}{*}{5} & \multirow{7}{*}{$0,027 *$} \\
\hline $1-5$ y1l arası & 77 & 160,90 & & & \\
\hline 6-10 y1l arasi & 44 & 135,10 & & & \\
\hline $\begin{array}{c}11-15 \text { y1l } \\
\text { arasi }\end{array}$ & 37 & 181,49 & & & \\
\hline $\begin{array}{c}16-20 \text { y1l } \\
\text { aras1 }\end{array}$ & 14 & 164,61 & & & \\
\hline $\begin{array}{c}21 \text { y1l ve } \\
\text { üzeri }\end{array}$ & 122 & 158,14 & & & \\
\hline Toplam & 309 & & & & \\
\hline
\end{tabular}

${ }^{*} \mathrm{p}<0,05$ anlamlılık düzeyinde ilişki anlamlı

Tablo 10'da yer alan veri sonuçları incelendiğinde; aylık gelir $(p=0,012<0,05)$ ve Şirince köyünde yaşama süresi $(p=0,027<0,05)$ değişkenleri ile turizmin olumlu etki ve etkileşimi arasında anlamlı bir farklılık olduğu tespit edilmiştir. Kruskal-Wallis Testi sonucunda aylık gelir değişkeninin sıra ortalamasına göre; turizmin olumlu etki ve etkileşiminden en çok etkilenen grup 1001-1500 TL arasında gelir elde edenlerdir. En az etkilenen ise; 4001 TL ve üzeri gelir elde eden gruptur. Gelir durumu arttıkça turizmin olumlu etki ve etkileşiminin yerel halkı etkileme düzeyinin azaldığı görülmektedir. Elde edilen gelir miktarının üst seviyede olduğu grup açısından turizmin olumlu etkisi ve etkileşiminin diğer gruplara nazaran çok az olduğu ve bu noktada turizmin sadece gelir kaynağı görülmesinin yanı sıra doyuma da ulaşıldığı sonucu çıkarılabilmektedir. Diğer sıra ortalamaları incelendiğinde, 1001-1500 TL arasında gelir elde edenlerden sonra, turizmin olumlu etki ve etkileşiminden en çok etkilenenler sırasıyla; 1001-2000 TL arası, 1000 TL'den az, 20013000 TL arası ve 3001-4000 TL arası grup gelmektedir. Gelir düzeyi daha az ve normal seviyede bulunan katılımcı yerel halk açısından henüz doyum söz konusu olmadığı için turizm faaliyetlerine bakış açısı daha farklıdır. 
Kruskal-Wallis Testi sonucundaki Şirince'de yaşama süresi değişkeninin sıra ortalamalarına göre ise; turizmin olumlu etki ve etkileşiminden en çok etkilenen grup 11-15 yıl arasında olup Şirince'de yaşayan yerel halktır. En az etkilenen ise; 1 yıldan az süredir köyde yaşayanlardır. Şirince' de yaşama süresinin uzun yıllar olması yerel halk tarafindan turizmin olumlu etkisinin ve etkileşiminin yoğun hissedilmesini sağlamıştır. Bölgede uzun süredir yaşıyor olmak her konuda yöre hakkında bilgi sahibi olmanın yanı sıra yaşanan etkilerin de az ya da çok olmasını belirlemektedir. Bu nedenle Şirince köyünde 1 yıldan az yaşayan katılımcıların, turizmin olumlu etki ve etkileşiminden daha az etkilendiği görülmektedir.

Şirince'de yaşama süresi değişkenine göre diğer gruplardaki sıra ortalamaları incelendiğinde; turizmin olumlu etki ve etkileşiminden en fazla etkilenen 11-15 yıl arasında köyde yaşayan katılımcı gruptan sonra 16-20 y1l arasındakiler gelmektedir. Daha sonrasında sirasıyla; 1-5 y1l arası, 21 yıl ve üzeri ve 6-10 yıl arası gelmektedir. Uzun yıllardır ve hatta Şirince’nin yerlisi olup tüm hayatını burada geçiren köylüler, turizmin gelişimine ve ilerlemesine şahit olmaları ile birlikte yerel halkın ekonomik kaynağı yıllar içerisinde değişerek turizme dayanmıştır. Bu nedenlerden dolayı Şirince'de yaşama süresi fazla olan katılımcı yerel halka göre turizmin olumlu etki ve etkileşimi, köyde yaşama süresi az olan katılımcı yerel halka göre daha fazla hissedilmektedir.

Kültürel etkinin yaş, eğitim durumu, Şirince'de yaşama süresi ve aylık gelir değişkenlerine göre farklılaşıp farklılaşmadığını saptamak amacıyla yapılan Kruskal-Wallis testinin sonuçları Tablo 11'de yer almaktadır. Yapılan Kruskal-Wallis testi sonucunda yaş ve Şirince' de yaşama süresi ile turizmin kültürel etkisi arasında anlamlı bir farklılık tespit edilemezken; aylık gelir $(p=0,005<0,01)$ ve eğitim $(p=0,023<0,05)$ değişkenleri ile turizmin kültürel etkisi arasında anlamlı bir farklılık olduğu tespit edilmiştir.

Tablo 11. Kültürel Etkinin Yaş, Eğitim Durumu, Şirince'de Yaşama Süresi ve Aylık Gelir Değişkenlerine Göre Farklılığını Gösteren Kruskal-Wallis Tablosu

\begin{tabular}{|c|c|c|c|c|c|}
\hline Değişken & $\mathbf{N}$ & $\begin{array}{c}\text { Sira } \\
\text { Ortalaması }\end{array}$ & Ki-Kare & $\begin{array}{c}\text { Serbestlik } \\
\text { Derecesi }\end{array}$ & p \\
\hline \multicolumn{7}{|c|}{ Yaş } & & \\
\hline $20-30$ & 90 & 152,84 & & \multirow{2}{*}{0,646} \\
\hline $31-40$ & 82 & 146,30 & \multirow{2}{*}{2,491} & & \\
\hline $51-50$ & 58 & 169,22 & & & \\
\hline 61 ve üzeri & 54 & 154,38 & & & \\
\hline
\end{tabular}




\begin{tabular}{|c|c|c|c|c|c|}
\hline Toplam & 309 & & & & \\
\hline \multicolumn{6}{|c|}{ Aylık Gelir } \\
\hline 1000 'den az & 34 & 187,22 & \multirow{7}{*}{16,922} & \multirow{7}{*}{5} & \multirow{7}{*}{$0,005^{* *}$} \\
\hline $1001-1500$ & 25 & 190,82 & & & \\
\hline $1501-2000$ & 51 & 160,13 & & & \\
\hline $2001-3000$ & 116 & 136,79 & & & \\
\hline $3001-4000$ & 51 & 165,95 & & & \\
\hline $\begin{array}{c}4001 \text { ve } \\
\text { üzeri }\end{array}$ & 32 & 133,17 & & & \\
\hline Toplam & 309 & & & & \\
\hline \multicolumn{6}{|c|}{ Eğitim } \\
\hline İlkokul & 92 & 146,88 & \multirow{5}{*}{4,368} & \multirow{5}{*}{3} & \multirow{5}{*}{0,224} \\
\hline Lise & 125 & 157,40 & & & \\
\hline Ön lisans & 41 & 141,77 & & & \\
\hline $\begin{array}{l}\text { Lisans ve } \\
\text { üzeri }\end{array}$ & 51 & 174,41 & & & \\
\hline Toplam & 309 & & & & \\
\hline \multicolumn{6}{|c|}{ Şirince'de Yaşama Süresi } \\
\hline 1 yildan az & 22 & 126,20 & \multirow{7}{*}{10,055} & \multirow{7}{*}{5} & \multirow{7}{*}{0,074} \\
\hline $1-5$ y1l aras1 & 70 & 155,86 & & & \\
\hline $6-10$ y1l arasi & 44 & 161,16 & & & \\
\hline $\begin{array}{c}11-15 \text { y1l } \\
\text { aras1 }\end{array}$ & 37 & 138,05 & & & \\
\hline $\begin{array}{c}16-20 \text { y1l } \\
\text { aras1 }\end{array}$ & 14 & 212,11 & & & \\
\hline 21 ve üzeri & 122 & 156,07 & & & \\
\hline Toplam & 309 & & & & \\
\hline
\end{tabular}

** $\mathrm{p}<0,01$ anlamlılık düzeyinde ilişki anlamlı

Tablo 11'de yer alan sonuçlar incelendiğinde; aylık gelir $(\mathrm{p}=0,005<0,01)$ ile turizmin kültürel etkisi arasında anlamlı bir farklılık olduğu tespit edilmiştir. Kruskal-Wallis Testi sonucundaki sıra ortalamalarına göre; aylık gelir değişkeninde turizmin kültürel etkilerinden en çok etkilenen grup 1001-1500 TL arasında gelir elde edenlerdir. En az etkilenen ise; 4001 TL ve üzeri gelir elde eden gruptur. Turizmin kültürel etkilerinden en çok etkilenen gruptan sonra gelenler sirasıyla; 1000 TL'den az, 3001-4000 TL aras1, 1501-2000 TL aras1 ve 2001-3000 TL arasinda gelir elde edenlerdir. Turizmin kültürel etkileri yerel halkın aylık gelir değişkenine göre elde edilen verilerin analizi değerlendirildiğinde; gelir düzeyi yüksek seviyede olan katılımcılara göre gelir düzeyi düşük ve normal olan yerel halkın kültürel etkilerden daha çok etkilendiği görülmektedir. Çünkü turizm mevsiminin yoğun yaşandığı dönemlerde yapılan bu kültürel faaliyetlere katılanları oluşturan kesim kültürel etkileri en çok yaşayanlardır. 
Araştırmada yer alan gruplar arasındaki farklılıkları tespit etmek amacıyla Mann-Whitney U Testi kullanılarak analiz edilmiştir. Aşağıda yer alan Tablo 12'de cinsiyet değişkeninin olumsuz etki, olumlu etki ve etkileşim ve kültürel etkiye ilişskin Mann-Whitney U Testi sonuçları yer almaktadır.

Tablo 12. Cinsiyet Değişkenine Göre Olumsuz Etki, Olumlu Etki ve Etkileșim ve Kültürel Etkiye İlişkin Mann-Whitney U Testi

\begin{tabular}{|c|c|c|c|c|c|c|}
\hline & $\begin{array}{c}\text { Cinsiye } \\
\mathbf{t}\end{array}$ & $\mathbf{N}$ & $\begin{array}{c}\text { Sira } \\
\text { Ortalaması }\end{array}$ & $\begin{array}{l}\text { Siralama } \\
\text { Toplamı }\end{array}$ & $\begin{array}{c}\text { Mann } \\
\text { Whitney } \\
\mathrm{U}\end{array}$ & $\mathbf{p}$ \\
\hline \multirow{2}{*}{$\begin{array}{c}\text { Olumsuz } \\
\text { Etki }\end{array}$} & Kadın & 143 & 162,16 & 23189,00 & \multirow{2}{*}{10845,000} & \multirow{2}{*}{0,189} \\
\hline & Erkek & 166 & 148,83 & 24706,00 & & \\
\hline \multirow{2}{*}{$\begin{array}{c}\text { Olumlu } \\
\text { Etki ve } \\
\text { Etkileşim }\end{array}$} & Kadın & 143 & 158,82 & 22711,00 & \multirow[b]{2}{*}{11323,000} & \multirow[b]{2}{*}{0,478} \\
\hline & Erkek & 166 & 151,71 & 25184,00 & & \\
\hline \multirow{2}{*}{$\begin{array}{c}\text { Kültürel } \\
\text { Etki }\end{array}$} & Kadın & 143 & 161,31 & 23068,00 & \multirow{2}{*}{10966,000} & \multirow{2}{*}{0,237} \\
\hline & Erkek & 166 & 149,56 & 24827,00 & & \\
\hline
\end{tabular}

Tablo 12'e göre; olumsuz etki, olumlu etki ve etkileşim ve kültürel etkinin cinsiyet değişkenine göre anlamlı bir şekilde farklılaşıp farklılaşmadığını belirlemek üzere yapılan parametrik olmayan Mann-Whitney U Testi sonucunda, cinsiyet değişkenine göre olumsuz etki ( $\mathrm{p}=0,189>0,05)$, olumlu etki ve etkileşim $(p=0,478>0,05)$ ve kültürel etki $(p=0,237>0,05)$ arasında anlamlı bir farklılık tespit edilmemiştir. Kadın katılımcıların olumsuz etki boyutuna ilişkin sıra ortalaması 162,16 iken erkek katılımcıların olumsuz etki boyutuna ilişkin sıra ortalaması 148,83'tür. Kadın katılımcıların erkek katılımcılara göre turizmin olumsuz etkilerinden daha çok etkilendiği görülmektedir. Bu sonuca göre; turizmin olumsuz etkisi cinsiyete göre anlamlı bir farklılık göstermemektedir.

Olumlu etki ve etkileşim boyutuna ilişkin Mann-Whitney U Testi sonucuna göre; kadın katılımcıların sıra ortalaması 158,82 erkek katılımcıların ise 151,71'dir. Kadın katılımcılar erkek katılımcılara göre turizmin olumlu etki ve etkileşimi daha çok görülmektedir. Olumlu etki ve etkileşim boyutu cinsiyete göre anlamlı bir farklılık göstermemektedir. 
Kültürel etki boyutuna ilişkin sonuçlara göre; kadın katılımcıların sıra ortalaması 161,31 iken erkek katılımcıların sıra ortalaması 149,56'dır. Erkek katılımcılar kadın katılımcılara göre turizmin kültürel etkilerini daha az yaşamaktadırlar. $\mathrm{Bu}$ sonuca göre ise, turizmin kültürel etkileri boyutunda cinsiyete göre istatistiksel açıdan anlamlı bir farklılık görülmemektedir.

\section{Sonuç ve Öneriler}

Günümüzde teknolojinin geldiği nokta sayesinde bir yerden başka bir yere seyahat etmek oldukça kolay bir hal almıştır. Bu durumda da uzaklık algısı, geçmişe göre farklılık göstermektedir. Ulaşımın bu denli kolay sağlanması insanların seyahat etme olanaklarının artmasını sağlamaktadır. $\mathrm{Bu}$ seyahatler sonucunda da turizm hareketleri yoğunlaşmaktadır. Sadece teknolojinin gelişmesi değil aynı zamanda insanların boş zamanlarının artması da turizmi yoğunlaştıran diğer bir nedendir. Her yıl milyonlarca insanın kitlesel turizmi oluşturmasının da belli başlı sonuçları vardır. Bu sonuçların başında da turizmin etkileri gelmektedir. Bu etkiler; çevresel, ekonomik, sosyal ve sosyo-kültürel olarak ayrılmaktadır.

Araştırma kapsamında turizmin sosyo-kültürel etkisi ele alınmaktadır. Her yıl yaklaşık 1,5 milyon turistin uğrak noktası olan Şirince köyünde turizmin yerel halk üzerine olan etkisi değerlendirilmektedir. Araştırma sonucunda elde edilen veriler doğrultusunda; Şirince köyünün yerlisi olan kesimin, olmayandan az olduğu tespit edilmiştir. Bunun nedeni ise eğitim, evlilik, iş gibi sebeplerden dolayı genç nüfusun köyden kente göç etmek zorunda kalması ve bununla birlikte köye turizm amaçlı gelip işletme sahibi olma isteğinde bulunan insanlardır. Kısacası, köyden bir kesim çıkarken bir kesim turizme hizmet etmek amacı ile gelmektedir. Bu nedenle de Şirince'nin yerlisine göre dışardan gelenlerin oranı daha yüksektir. Şirince köyünün yerel halkı turizm ile bütünleşmiş bir durumdadır. Uzun yıllardır turizmin içerisinde bulunmalarının buna etkisi büyüktür. Gelir kaynaklarının başında turizmin gelmesi, yerel halkın turizme bakış açısında da önemli bir yere sahiptir. Çünkü ne kadar gelişir ve iyileşirse, gelirlerinde de o derece olumsuz sonuçlar yaşanacaktır. Köy halkı turistler ile her zaman iyi ilişkiler kurma eğilimindedirler. Şirince köyünde turizm sezonlarında faaliyetlerin artması yerel halk tarafından olumlu karşılanmaktadır. Yapılan faaliyetler bölgeye karşı turistik talebin artmasını sağlamaktadır. Turistik talebin artması ile de bölgeye ziyaretlerin artmasının sonucunda yerel halkın bu durumdan memnun olduğu görülmektedir. Turistler gibi yerel halk da farklı kültürleri tanıma isteğindedirler. Turistler farklı 
kültürü görmek için bölgeleri ziyaret ederken, yerel halk gelen turistler ile iletişim kurarak kültür tanıma firsatı bulmaktadırlar. Bu durumda her iki tarafta birbirini tanımak ve anlamak için iyi ilişkiler kurmaktadırlar.

Kültürün önemli unsurlarından biri olan “dil” açısından yörede yapılan araştırma sonucunda, dilin bozulma durumunun ciddi boyutlarda olmadığı görülmektedir. Turizmin yerel halkın konuşma diline tamamen etki etmediğini söylemek doğru olmaz. Bunun nedeni ise yerel halkın belli bir kesiminin dile etkisi olduğunu savunmasıdır. Fakat çoğunluğun etki etmediğini belirtmesi nedeni ile henüz dil üzerinde değişimin boyutlarının ciddi olmadığı sonucuna varılmıştır.

Turizmin Şirince halkı üzerinde yaşam tarzının değişmesine sebep olduğuna dair elde edilen verilere göre; yerel halk fikir ayrılığını yoğun olarak yaşamıştır. Yörede yaşayan insanlar çoğunluk ile yaşam tarzının turizm nedeni ile değiştiğini belirtmiştir. Şirince köyünde yaşanan fikir ayrılı̆̆ı, aslında turizmin bir noktada yerel halkı etkisi altına aldı̆̆ını göstermektedir.

Sonuç olarak söylemek gerekir ki; Şirince köyünde yaşayan ve turizmle iç içe olan yerel halk turizmin ve turizm faaliyetlerinin gelişmesine olumlu yaklaşmaktadırlar. Yerel halkın fikir ayrılığı yaşadığı durumlar çok azdır. Turizmin gelişmesi ve iyileşmesi için yerel halkın bakış açısı önemli bir rol oynamaktadır.

\section{Kaynakça}

Avcıkurt, C. (2017). Turizm Sosyolojisi Genel ve Yapısal Yaklaşım. Ankara: Detay Yayıncılık.

Baştan, N. B. (2020). Turizmin Yerel Halk Üzerine Sosyo-Kültürel Etkileri: Şirince Köyü Örneği, Yayınlanmamış Yüksek Lisans Tezi, Pamukkale Üniversitesi Sosyal Bilimler Enstitüsü, Denizli.

Civelek, A. (2010). Turizmin Sosyal Yapıya ve Sosyal Değişmeye Etkileri, Selçuk Üniversitesi Sosyal Bilimler Meslek Yüksekokulu Dergisi, 13(1-2), ss. 331-350.

Correia, A., Kozak, M., \& Ferradeira, J. (2013). From tourist motivations to tourist satisfaction. International Journal of Culture, Tourism and Hospitality Research ,7(4), ss. 411-424. 
Çalışkan, U. (2003). Turizmin Yerel Halk Üzerindeki Etkileri ve Kuşadası İlçesi Uygulaması. Yayınlanmamış Yüksek Lisans Tezi, Dokuz Eylül Üniversitesi, Sosyal Bilimler Enstitüsü, İzmir.

Demircan, Ş. (2010). Turizmin Sosyo-Kültürel Etkileri: Antalya/Muratpaşa İlçesi Örneği, Yayınlanmamış Yüksek Lisans Tezi, Akdeniz Üniversitesi, Sosyal Bilimler Enstitüsü, Antalya.

Erturgut, Ş.B. (2014). Kırsal Yerleşmelerde Mimari Yapılaşmaların Ekolojik Açıdan İrdelenmesi: Ildırı ve Şirince Köyü Örnekleri, Yayınlanmamış Doktora Tezi, Ege Üniversitesi Fen Bilimleri Enstitüsü, İzmir.

Fleischer, A., \& Pizam, A. (1997). Rural tourism in Israel. Tourism Management, 18(6), ss. 367372.

Gürbüz, A. (2002). Turizmin sosyal çevreye etkisi üzerine bir araştırma. Teknoloji Dergisi, (1-2), ss. 49-59.

Jovičić, D. (2011). Socio-cultural impacts of contemporary tourism. Collegium Antropologicum, 35 (2), ss. 599-605.

Kaya, N. K. (2012). Şirince köyü örneğinde kırsal mimari mirasın kırsal turizmin gelişmesine katkısının tartışılması, Karamanoğlu Mehmetbey Üniversitesi Sosyal ve Ekonomik Araştırmalar Dergisi, (1), ss. 119-123.

Kınacı, B., Pehlivan Albuz, N., \& Seyhan, G. (2011). Turizm ve Çevre (Çevre Koruma) Ankara: Pegem Akademi.

Korkmaz, S. (1990). Turizmin ekonomik ve sosyal etkileri, İstanbul Üniversitesi İktisat Fakültesi Mecmuas1, 46, ss. 391-417.

OECD (1994), Tourism Strategies and Rural Development, Paris.

Semenderoğlu, A., \& Çakıcıoğlu, R. O. (2007). Şirince'de kültürel turizmin gelişimi. Dokuz Eylül Üniversitesi Buca Eğitim Fakültesi Dergisi, (22), ss. 174-184.

Sharpley, R. (2002). Rural tourism and the challenge of tourism diversification: the case of Cyprus. Tourism Management, 23(3), ss. 233-244. 
Skanavis, C., \& Sakellari, M. (2011). International tourism, domestic tourism and environmental change: environmental education can find the balance. Tourismos, 6(1), ss. 233-249.

Tayfun A. (2002). Turist yerli halk etkileşimi üzerine bir araştırma, G.Ü. Ticaret ve Turizm Eğitim Fakültesi Dergisi, 1, ss. 1-12.

Türkay, O., \& Yalçın Kayıkçı, M. (2018). Tarhana tezgâhlarından Çin malı tüccarlığına: Şirince'de turizmle iç içe geçen kültürleşme ve sosyo-kültürel dönüşüme bağlı sorunların analizi. Ege Academic Review, 18(4), ss. 645-660.

Usta, Ö. (2008). Turizm Genel ve Yapısal Yaklaşım, Ankara: Detay Yayıncılık.

Unur, K. (2004). Turizmin ekonomik etkilerinin ölçülmesi, Dokuz Eylül Üniversitesi Sosyal Bilimler Enstitüsü Dergisi, 6(4), ss. 114-142.

Var, T., Kaplan, M. D., \& Yurt, O. (2006). Challenges and opportunities of developing wine tourism in a small community in Turkey. E-Review of Tourism Research, 4(1), ss. 9-18.

Yazıcı, E. (2002). Yirminci yüzyılda gelenekten moderniteye türk sosyo-kültürel yapısında gözlenen değişmeler, Gazi Üniversitesi İktisadi ve İdari Bilimler Fakültesi Dergisi, 4(2), ss. 223-245.

Yazıcıoğlu, Y., \& Erdoğan, S. (2004). Spss Uygulamalı Bilimsel Araştırma Yöntemleri, Ankara: Detay Yayıncılik.

İnternet Kaynakları

Anadolu Ajansı. (2018). 'Kıyamet Köyü' Şirince Şöhretinin Zirvesinde. https://www.ntv.com.tr/galeri/seyahat/kiyamet-koyu-sirince-sohretininzirvesinde,VvljtYGDK0ymDeXpYeNlGQ/678YbmgjGE2jMVsDHN8duQ (17.02.2020).

Coğrafya Bilimi. (Kasım, 2017). Turizmin Önemi ve Etkileri. https://www.cografyabi limi.gen.tr/turizmin-onemi-etkileri/ $(12.06 .2020)$.

Evrensel. (Haziran, 2005). Şirince'nin Öyküsü. https://www.evrensel.net/haber/162283/ sirincenin-oykusu $(06.06 .2020)$. 
Kurt, H. ve Bal, E. (Temmuz, 2018). Tarım ve Orman Dergisi, Hem Doğa İle İç İçe Olun Hem De Kırsal Kalkınmaya Katkıda Bulunun. http://www.turktarim.gov.tr /Haber/112/hemdogayla-ic-ice-olun-hem-de-kirsal-kalkinmaya-katkida-bulunun (14.06.2020).

Selçuk Kaymakamlığı. (Kasım, 2019). Şirince. http://www.selcuk.gov.tr/sirince (06.06.2020).

Şirince Köyü Nüfusu. (2019). www.nufusu.com (16.05.2019).

TRT Haber. (Temmuz, 2018). Șirince Yılda Ortalama 1.5 Milyon Ziyaretçi Ağırlıyor. https://www.trthaber.com/haber/yasam/sirince-yilda-ortalama-15-milyon-ziyaretciagirliyor-376478.html (06.06.2020).

Türkiye Kültür Portal1, Selçuk-Şirince Köyü-İzmir. https://www.kulturportali.govtr/turki ye/izmir/gezilecekyer/selcuk-sirince-koyu (18.02.2020). 